\title{
Estudo comparativo da medida da rotação vertebral pelos métodos de Nash \& Moe e método de Raimondi
}

\author{
Comparative study of the measurements of the vertebral rotation using
} Nash \& Moe and Raimondi methods

Helton L. A. Defino ${ }^{1}$, Paulo Henrique Mendes de Araújo ${ }^{2}$

\section{RESUMO}

Neste estudo foram avaliados a sensibilidade e precisão dos métodos de Nash e Moe e de Raimondi para a medida da rotação da vértebra torácica e lombar. Três cirurgiões de coluna avaliaram, independentemente, as radiografias de uma vértebra torácica (T9) e de uma vértebra lombar (L2) com graus de rotação que variaram de $0^{\circ}$ a $60^{\circ}$ e estabeleceram valores de acordo com o método de Nash e Moe e o método de Raimondi.Foram estudadas a concordância entre os examinadores para um determinado método, a variação das medidas obtidas na vértebra torácica e lombar a partir de uma mesma rotação real conhecida e a correlação entre um valor real conhecido de rotação vertebral e a sua estimativa pelos métodos utilizados no estudo . Os resultados mostraram boa concordância entre os examinadores para o método de Nash e Moe, tanto para a vértebra torácica ( $\mathrm{k}$ médio $=0,66)$, quanto para a lombar ( $\mathrm{k}$ médio $=0,80$ ). Pelo método de Raimondi não houve diferença significativa entre os examinadores para a vértebra torácica, no entanto, para a vértebra lombar houve baixa reprodutibilidade do método.Para uma mesma rotação na vértebra torácica e lombar os resultados foram não concordantes pelo método de Nash e Moe, e pelo método de Raimondi os valores observados para a vértebra torácica foram significativamente maiores que os da vértebra lombar. A correlação entre os valores reais e as estimados pelo método de Raimondi para a vértebra torácica mostrou que houve diferença significativa produzida em função da rotação até $20^{\circ}$ graus, já para a vértebra lombar, os valores obtidos foram muito próximos do real.

Descritores: Rotação; Coluna vertebral; Escoliose; Método de avaliação

\section{INTRODUÇÃO}

A escoliose é uma deformidade tridimensional complexa do tron$\mathrm{co}$, destacando-se o seu desvio lateral e a rotação dos corpos vertebrais entre os vários componentes patológicos da deformidade ${ }^{(11,12)}$. A rotação dos corpos vertebrais ocorre para o lado da convexidade da curva e a sua manifestação clínica juntamente com a deformidade das costelas na coluna torácica ou dos processos espinhosos na coluna lombar é denominada de giba ou gibosidade ${ }^{(4)}$. $O$ grau de

Trabalho realizado na Faculdade de Medicina de Ribeirão Preto da Universidade de São Paulo - Departamento de Biomecânica, Medicina e Reabilitação do Aparelho Locomotor

1 - Professor Associado do Departamento de Biomecânica, Reabilitação e Medicina do Aparelho Locomotor da Faculdade de Medicina de Ribeirão Preto- USP.

2 - Médico Residente da Disciplina de Ortopedia do Hospital das Clínicas de Ribeirão Preto.

Endereço para correspondência: Av. Bandeirantes 3900 - Ribeirão Preto São Paulo - Sp - CEP 14049-900 - email: hladefin@fmrp.usp.br

Trabalho recebido em 10/04/2004. Aprovado em 20/06/2004

\section{SUMMARY}

The sensibility and precision of the Nash and Moe and Raimondi methods were evaluated in this study for the measurement of the rotation of the thoracic and the lumbar vertebra. Three spine surgeons evaluated, independently, the x-rays of a thoracic vertebra (T9) and of a lumbar vertebra (L2) with varying rotational degrees from $0^{\circ}$ to $60^{\circ}$ and established values in agreement with the Nash and Moe method and the Raimondi method. The agreement among the examiners as to a certain method, the variation of the measures obtained for the thoracic and the lumbar vertebra, starting from a same known actual rotation and the correlation between a known true value of vertebral rotation and its forecast prepared through the methods used in the study were perused. The results showed good agreement among the examiners for the Nash and Moe method, so much for the thoracic vertebra (average $k=0,66$ ), as for the lumbar (average $k=0,80$ ). Using the Raimondi method there was no significant difference among the examiners for the thoracic vertebra. However, there was a low reproducibility of the method for the lumbar vertebra. For a same rotation of the thoracic and lumbar vertebra the results were non-concordant for the method of Nash and Moe, and for the Raimondi method the values observed for the thoracic vertebra were significantly larger than the ones for the lumbar vertebra. The correlation between the true values and the estimated values for the Raimondi method for the thoracic vertebra showed that there was a significant difference produced in function of the rotation up to $20^{\circ}$ degrees, however for the lumbar vertebra the obtained values were very close to the actual.

Key words: Rotation; Spine; Scoliosis; Evaluation method.

\section{INTRODUCTION}

Scoliosis is a complex three-dimensional deformity of the trunk, the lateral deviation and the rotation of the vertebral bodies among the several pathological components of the deformity are emphasized ${ }^{(11,12)}$. The rotation of the vertebral bodies occurs to the side of the curve convexity and its clinical manifestation with the deformity of the ribs in the thoracic column or of the thorny processes in the lumbar column is called a hump or a gibbus ${ }^{(4)}$. The rotational grade of the vertebrae in the scoliosis is related to the cosmetic and aesthetic alterations of the patients, and measurements were developed, in addition to the clinical

Work performed at the Department of Biomechanics, Medicine and Rehabilitation of the Locomotor Apparatus, Faculty of Medicine University of São Paulo, Ribeirão Preto, SP, Brazil

1 - Associate Professor of the Locomotion Apparatus' Biomechanics, Rehabilitation and Medicine Department of the Ribeirao Preto School of Medicine - USP.

2 - Resident Doctor of the Orthopedics Discipline at the Clinicas Hospital in Ribeirao Preto.

Adress:Av. Bandeirantes 3900 - Ribeirão Preto - São Paulo - Sp - CEP 14049-900 - email: hladefin@fmrp.usp.br 
rotação das vértebras nas escolioses está relacionado com as alterações cosméticas e estética dos pacientes, e além dos métodos clínicos para a sua avaliação, foram desenvolvidas mensurações utilizando-se as radiografias convencionais, destacando-se os métodos descritos por Cobb, Nash e Moe, Perdriolle e Raimondi $(2,3,8,9,10)$.

A rotação vertebral tem sido um parâmetro muito enfatizado na avaliação dos pacientes e dos resultados dos procedimentos terapêuticos, e o objetivo do nosso estudo foi avaliar o grau de precisão e a concordância da medida entre diferentes examinadores relacionadas a dois métodos ( método de Nash e Moe e método de Raimondi), que tem sido utilizados na prática clínica para a avaliação da rotação vertebral em pacientes portadores de escoliose.

\section{MATERIAL E MÉTODOS}

Foram utilizadas no estudo uma vértebra torácica (T9) e uma vértebra lombar (L2) de indivíduo adulto e sem alterações da sua morfologia.

Foi confeccionado um dispositivo, no qual as vértebras eram individualmente fixadas, e por meio de um goniômetro o grau de sua rotação podia ser mensurado, tendo sido realizado radiografias em AP por meio da técnica convencional, desde a posição neutra (0æ\%) até $60 æ \%$ de rotação, com intervalo de $5 æ \%$ entre a realização das radiografias.(Figura 1)

As radiografias foram avaliadas independentemente por 3 cirurgiões de coluna, tendo sido proposto que cada um examinasse as radiografias e determinasse as medidas das rotações vertebrais de acordo com o método de Nash e Moe e método de Raimondi.

O método de Nash e Moe é baseado na relação entre os pedículos vertebrais e o centro do corpo vertebral nas radiografias em anteroposterior, sendo a rotação classificada em cinco diferentes graus de acordo com o afastamento dos pedículos. Nas situações em que os pedículos estão eqüidistantes das margens laterais dos corpos vertebrais, não há rotação vertebral, e é considerado como grau 0. À medida que a projeção do pedículo da vértebra apical desloca-se para a linha média nas radiografias em AP,o grau de rotação progride na escala de avaliação, atingindo o maior valor (grau IV) quando ultrapassa essa linha. (Figura 2)

O método de Raimondi utiliza a projeção dos pedículos vertebrais e a largura da vértebra como referência para as medidas. O maior eixo do pedículo é demarcado e mensurado no lado da convexidade da curva, e a distância da linha longitudinal desde o pedículo até a borda da vértebra no lado convexo é mensurado. Esses dois valores são transportados para a régua, obtendo-se o valor da rotação. (Figura 3)

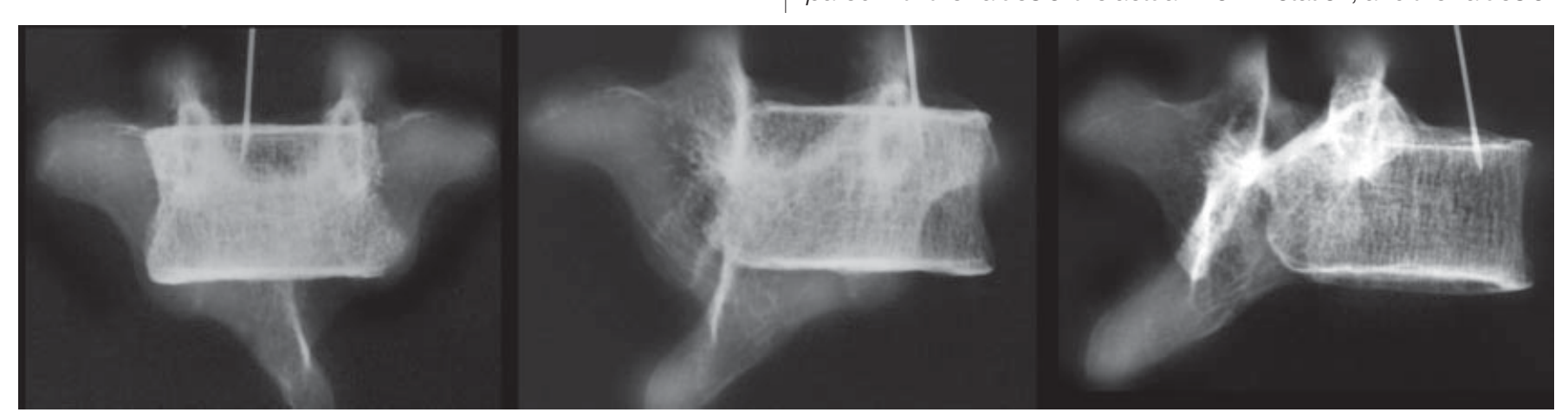

Figura 1 - Radiografias da vértebra torácica nos diferentes graus de rotação. $0^{\circ}(A), 30^{\circ}(B), 60^{\circ}(C)$. Figure 1 - Thoracic vertebra X-rays in different rotational degrees. $0^{\circ} \circ(A), 30^{\circ} \circ(B), 600^{\circ}(C)$. methods for its evaluation, using conventional X-rays, highlighting the methods described by Cobb, Nash \& Moe, Perdriolle e Raimondi $(2,3,8,9,10)$.

The vertebral rotation has been a very emphasized parameter in the patients' evaluation and of the results of the therapeutic procedures, and the objective of our study was to evaluate the degree of precision and the agreement as to the measure, among different examiners, related to two methods (Nash \& Moe and Raimondi methods), that have been used in clinical practice for the evaluation of the vertebral rotation in scoliosis patients.

\section{MATERIAL AND METHODS}

In this study we used one thoracic vertebra (T9) and one lumbar vertebra (L2) from an adult individual and without any alterations to its morphology.

A device elaborated, in which the vertebrae were individually fastened, the degree of its rotation could be measured by goniometry, and $x$-rays were taken in AP using the conventional technique, from the neutral position $\left(0^{\circ}\right)$ up to $60^{\circ}$ of rotation, with a $5^{\circ}$ interval of between the x-rays. (Figure 1)

The x-rays were appraised independently by 3 spine surgeons, and it was proposed that each one examined the x-rays and determined the measurements of the vertebral rotations in agreement with the Nash \& Moe and Raimondimethods.

The method of Nash \& Moe is based on the relationship between the vertebral pedicles and the center of the vertebral body in the x-rays, in anteroposterior, and the rotation is classified in five different degrees according to the removal of the pedicles. There is no vertebral rotation in the situations in that the pedicles are halfway of the lateral margins of the vertebral bodies, and it is considered as a degree $O^{\circ}$. As the projection of the pedicle of the apical vertebra moves towards the median line in the $x$-rays in AP, the rotational degree progresses in the evaluation scale, reaching the largest value (degree $N$ ) when it crosses that line. (Figure 2)

The Raimondi method uses the projection of the vertebral pedicles and the width of the vertebra as a reference for the measuring. The largest axis of the pedicle is demarcated and measured on the side of the curve convexity, and the distance of the longitudinal line from the pedicle to the border of the vertebra on the convex side is measured. Those two values are transported to the ruler, and the value of the rotation is, thus, obtained. (Figure 3)

The measures of the vertebral rotation of the thoracic vertebra and of the lumbar vertebra determined by the selected methods were compared with the values of the actual known rotation, and the values of 
As medidas da rotação vertebral da vértebra torácica e da vértebra lombar determinadas pelos métodos selecionados foram comparadas com os valores da rotação real que era conhecido, e os valores das medidas obtidas nas mensurações dos 3 examinadores foram comparadas.

O estudo estatístico dos valores das medidas da rotação obtida pelos 3 examinadores foi realizado por meio do teste "t de Student", "Qui-quadrado" e coeficiente kappa, dependendo do tipo da variável estudada. the measures obtained in the 3 examiners' mensuration were compared.

The statistical study of the values of the measures of the rotation obtained by the 3 examiners was performed through a test "t of Student", "Qui-square" and kappa coefficient, depending on the type of the studied variable.
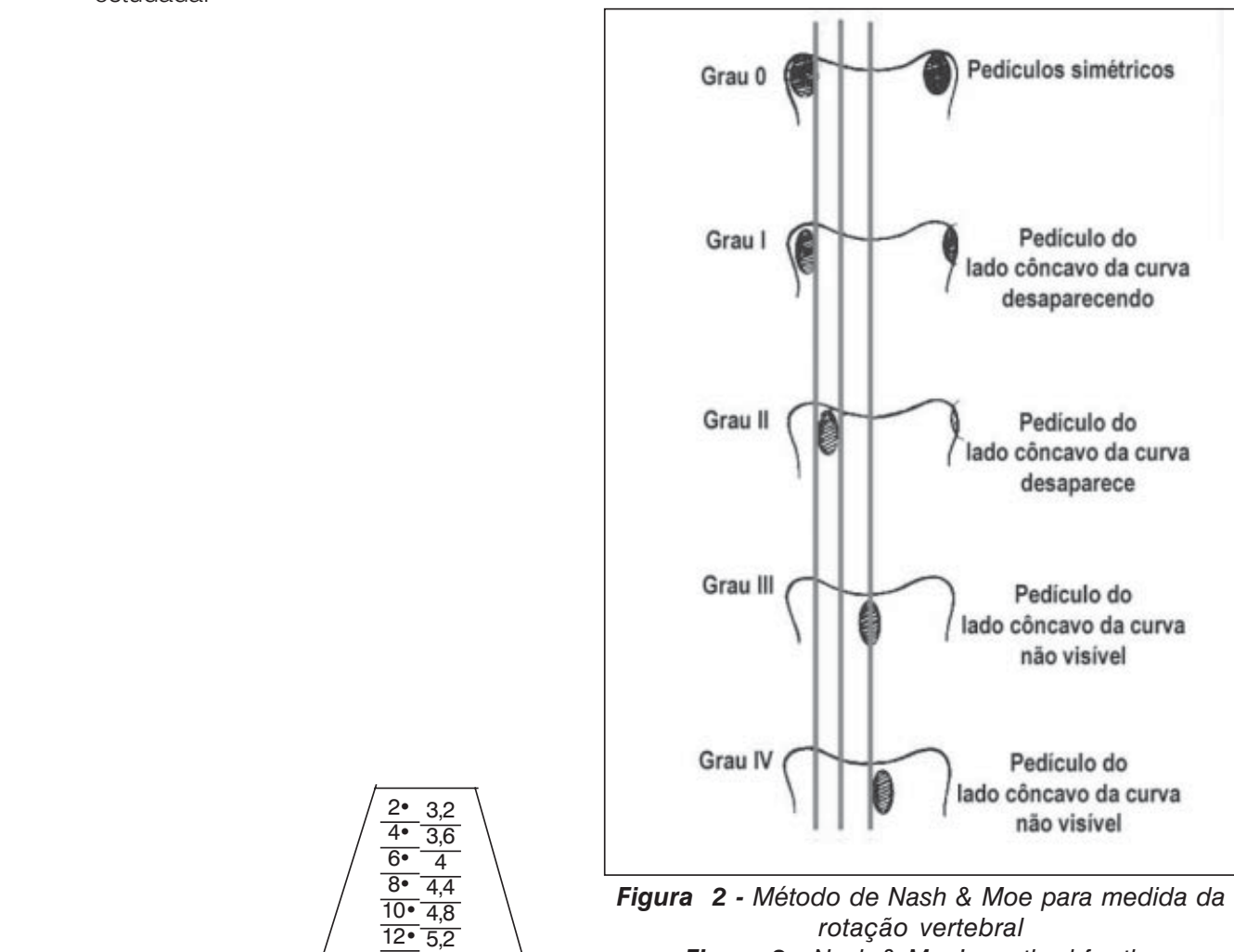

Figure 2 - Nash \& Moe's method for the measurement of the vertebral rotation

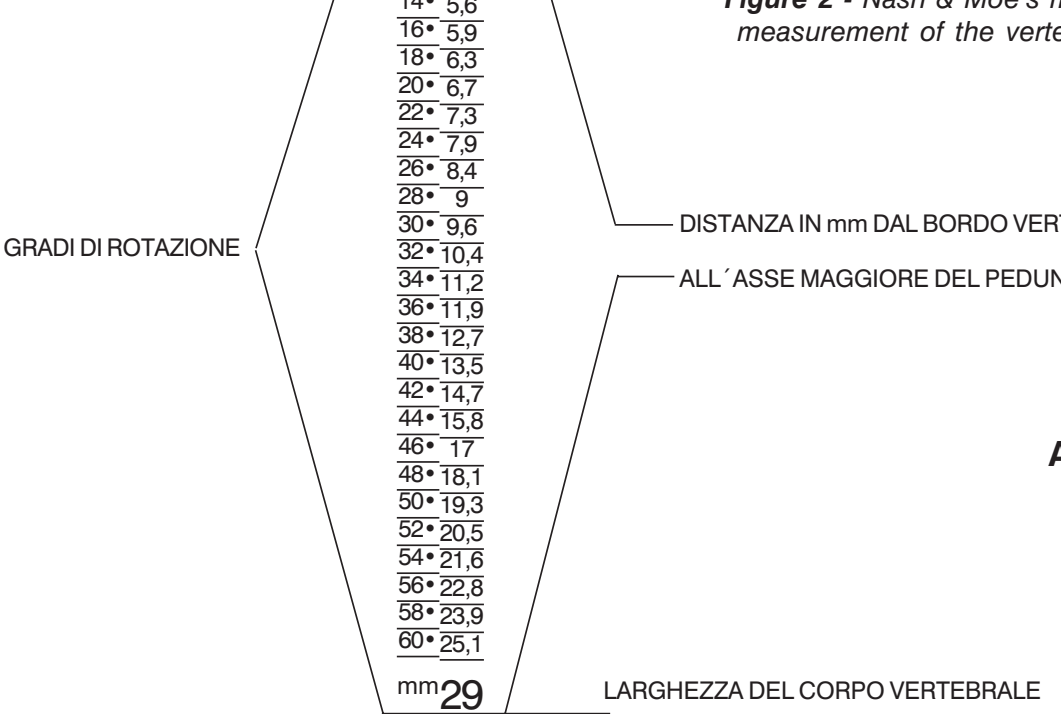

Figura $3 \boldsymbol{A}$ - Régua utilizada para a mensuração da rotação vertebral no método de Raimondi.

Figure $3 \mathbf{A}$ - Ruler used for the measurement of the vertebral rotation according to the Raimondi's method.
A
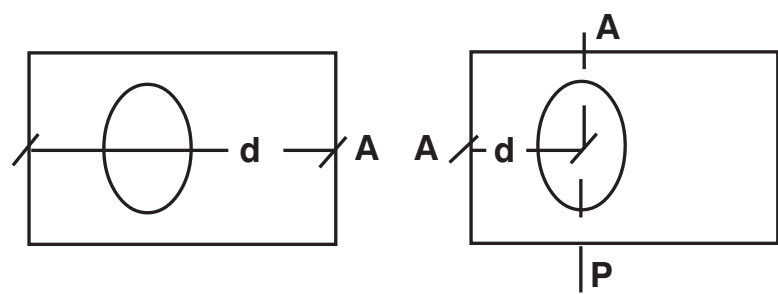

Figura 3B - Medida parâmetro relacionado com o pedículo vertebral do lado da convexidade da curva (d), assim como a largura do corpo vertebral (A-A'). Esses dados são transportados para a régua e obtém-se diretamente o valor da rotação vertebral.

Figure 3B - Standard measure related to the vertebral pedicle shadow offset image (d) as well as the width of the vertebral body $\left(A-A^{\prime}\right)$. These data are transported to a rule and the vertebral rotational values are obtained directly. 
RESULTADOS

Os valores das medidas individuais de cada examinador pelo método de Nash e Moe e pelo método de Raimondi estão ilustrados na Tabela1.

A concordância entre os valores individuais da rotação obtidos por meio do método de Nash e Moe foi comparada por meio da análise entre os pares de examinadores, tendo sido utilizado o coeficiente Kappa (K), que varia de 0 a 1. A concordância é considerada excelente para valores de $k>0,80$; boa para valores entre 0,60 e 0,80; regular entre 0,40 e 0,60; e fraca para valores menores que 0,40. Esses valores estão ilustrados na Tabela 2 , e foi observado maior grau de concordância entre os examinadores nas medidas da vértebra lombar (coeficiente médio de 0,80) em relação à vértebra torácica, utilizandose o método de Nash e Moe.

\section{RESULTS}

The values of each examiner's individual measures by the Nash \& Moe method and by the Raimondi method coefficient are illustrated in Table 1.

The agreement among the individual values of the rotation obtained through Nash \& Moe method was compared by analysis among the pairs of examiners, using the coefficient Kappa $(K)$ that varies from o to 1. The agreement is considered excellent for $k>0,80$ values; $g o o d$ for values between 0,60 and 0,80; regular between 0,40 and 0,60; and weak for values under 0,40 . Those values are illustrated in Table 2, and a larger agreement degree was observed among the examiners in the measures of the lumbar vertebra (average coefficient of 0,80 ) in relation to the thoracic vertebra, using the Nash \& Moe method.

\begin{tabular}{|c|c|c|c|c|c|c|c|}
\hline \multirow{3}{*}{$\begin{array}{l}\text { Grau } \\
\text { Degree }\end{array}$} & \multirow{3}{*}{$\begin{array}{l}\text { Examinadores } \\
\text { Analized }\end{array}$} & \multicolumn{3}{|c|}{$\begin{array}{l}\text { Vértebra Torácica } \\
\text { Thoracic Vertebra }\end{array}$} & \multicolumn{3}{|c|}{$\begin{array}{l}\text { Vértebra Lombar } \\
\text { Lumbar Vertebra }\end{array}$} \\
\hline & & \multirow[b]{2}{*}{ Nash \& Moe } & \multicolumn{2}{|c|}{ Raimondi } & \multirow[b]{2}{*}{ Nash e Moe } & \multicolumn{2}{|c|}{ Raimondi } \\
\hline & & & & $\begin{array}{c}\text { Média } \\
\text { Average }\end{array}$ & & & $\begin{array}{c}\text { Média } \\
\text { Average } \\
\end{array}$ \\
\hline \multirow{3}{*}{0} & 1 & 0 & 9 & \multirow{3}{*}{9,33} & 0 & 6 & \multirow{3}{*}{5} \\
\hline & 2 & 0 & 10 & & 0 & 6 & \\
\hline & 3 & 0 & 9 & & 0 & 3 & \\
\hline \multirow{3}{*}{5} & 1 & 1 & 17 & \multirow{3}{*}{16} & 0 & 6 & \multirow{3}{*}{5} \\
\hline & 2 & 1 & 16 & & 0 & 6 & \\
\hline & 3 & 1 & 15 & & 0 & 3 & \\
\hline \multirow{3}{*}{10} & 1 & 1 & 26 & \multirow{3}{*}{27,66} & $\mathrm{I}$ & 7 & \multirow{3}{*}{5,33} \\
\hline & 2 & II & 28 & & 1 & 6 & \\
\hline & 3 & II & 29 & & 0 & 3 & \\
\hline \multirow{3}{*}{15} & 1 & II & 27 & \multirow{3}{*}{29} & 1 & 11 & \multirow{3}{*}{13} \\
\hline & 2 & II & 30 & & 1 & 16 & \\
\hline & 3 & II & 30 & & 1 & 12 & \\
\hline \multirow{3}{*}{20} & 1 & III & 38 & \multirow{3}{*}{37,66} & II & 19 & \multirow{3}{*}{18,33} \\
\hline & 2 & III & 38 & & II & 18 & \\
\hline & 3 & II & 37 & & II & 18 & \\
\hline \multirow{3}{*}{25} & 1 & II & 38 & & II & 17 & \\
\hline & 2 & III & 40 & 39,66 & II & 18 & 17 \\
\hline & 3 & III & 41 & & ॥ & 16 & \\
\hline & 1 & II & 39 & & II & 25 & \\
\hline 30 & 2 & III & 40 & 38,33 & II & 24 & 24 \\
\hline & 3 & III & 39 & & II & 23 & \\
\hline & 1 & IIII & 41 & & II & 27 & \\
\hline 35 & 2 & III & 40 & 40,66 & II & 26 & 26,66 \\
\hline & 3 & III & 41 & & ॥ & 27 & \\
\hline & 1 & III & 47 & & II & 39 & \\
\hline 40 & 2 & IV & 44 & 46 & III & 38 & 38 \\
\hline & 3 & IV & 47 & & III & 37 & \\
\hline & 1 & IV & 52 & & III & 39 & \\
\hline 45 & 2 & III & 52 & 51 & III & 40 & 39,33 \\
\hline & 3 & IV & 49 & & III & 39 & \\
\hline & 1 & IV & 55 & & III & 41 & \\
\hline 50 & 2 & IV & 54 & 56 & III & 42 & 41 \\
\hline & 3 & IV & 59 & & III & 40 & \\
\hline & 1 & IV & 58 & & IV & 43 & \\
\hline 55 & 2 & IV & 58 & 58,66 & IV & 44 & 42,66 \\
\hline & 3 & IV & 60 & & III & 41 & \\
\hline & 1 & IV & 58 & & IV & 48 & \\
\hline 60 & 2 & IV & 60 & 60 & IV & 48 & 47 \\
\hline & 3 & IV & 62 & & IV & 45 & \\
\hline
\end{tabular}

Tabela 1 - Valores obtidos pelos examinadores na avaliação de radiografias em AP de uma vértebra torácica e uma vértebra lombar, em rotações de 0 a

60 graus com intervalos de 5 graus, pelos métodos de Nash \& Moe e Raimondi e a média dos resultados nesta última escala.

Table 1 - Amounts obtained by the examiners in the evaluation of thoracic vertebrae and lumbar vertebrae $A P$ X-rays in a rotational span from $0^{\circ}$ to $60^{\circ}$ with 5o intervals, using the Nash \& Moe and Raimondi methods, and the average of the results for this last scale. 


\begin{tabular}{|l|c|c|c|c|}
\hline & Coef. Kappa & Desvio padrão & $\begin{array}{c}\text { Teste “t” } \\
\text { de student }\end{array}$ & $\begin{array}{c}\text { Nível de } \\
\text { Concordância }\end{array}$ \\
\hline Examinador 1 X Examinador 2 & 0,5 & 0,17 & 0,005 & regular \\
\hline Examinador 1 X Examinador 3 & 0,59 & 0,17 & $<0,001$ & regular \\
\hline Examinador 2 X Examinador 3 & 0,9 & 0,1 & $<0,001$ & excelent \\
\hline
\end{tabular}

Tabela 2 - Comparação estatística entre os resultados obtidos pelos examinadores pelo Método de Nash \& Moe para a vértebra torácica. Table 2 - Statistical comparison between the results obtained for thoracic vertebrae by the examiners using the Nash \& Moe method.

A comparação dos resultados individuais da rotação obtidos por meio do método de Raimondi foi realizado por meio do teste "t de Student", considerando-se o nível de significância (p) menor que 0,05, e estão ilustrados nas Tabelas 3 e 4 . Não foi observado concordância das medidas da vértebra torácica entre os examinadores, e na coluna lombar a concordância das medidas foi observada entre dois pares de examinadores.
The comparison of the individual rotation results obtained using the Raimondi method was performed using the "t of Student" test, considering the significance level (p) smaller than 0,05, and are illustrated in Tables 3 and 4 . Agreement of the measures of the thoracic vertebra was not observed among the examiners, and in the lumbar spine the agreement of the measures was observed among two pairs of examiners.

\begin{tabular}{|l|c|c|c|c|c|}
\hline & $\begin{array}{c}\text { Diferença } \\
\text { Média }\end{array}$ & $\begin{array}{c}\text { Desvio } \\
\text { Padrão }\end{array}$ & $\begin{array}{c}\text { Teste "t" } \\
\text { de Student }\end{array}$ & $\begin{array}{c}\text { Teste de } \\
\text { Wilcoxon (p) }\end{array}$ & $\begin{array}{c}\text { Divergiram } \\
\text { Significamente }\end{array}$ \\
\hline Examinador 1 X Examinador 2 & $-0,385$ & 1,66 & 0,42 & 0,35 & Não \\
Examinador 1 X Examinador 3 & -1 & 2,31 & 0,14 & 0,11 & Não \\
Examinador 2 X Examinador 3 & $-1,05$ & 2,1 & 0,31 & 0,32 & Não \\
\hline
\end{tabular}

Tabela 3 - Comparação estatística entre os resultados obtidos pelos examinadores pelo método de Raimondi para a vértebra torácica.

Table 3 - Statistical comparison between the results obtained by the examiners, using the Raimondi method for thoracic vertebrae.

\begin{tabular}{|l|c|c|c|c|c|}
\hline & $\begin{array}{c}\text { Diferença } \\
\text { Média }\end{array}$ & $\begin{array}{c}\text { Desvio } \\
\text { Padrão }\end{array}$ & $\begin{array}{c}\text { Teste "t" } \\
\text { de Student }\end{array}$ & $\begin{array}{c}\text { Teste de } \\
\text { Wilcoxon (p) }\end{array}$ & $\begin{array}{c}\text { Divergiram } \\
\text { Significamente }\end{array}$ \\
\hline Examinador 1 X Examinador 2 & $-0,308$ & 1,65 & 0,52 & 0,78 & Não \\
Examinador 1 X Examinador 3 & 1,62 & 1,45 & 0,002 & 0,006 & Sim \\
Examinador 2 X Examinador 3 & 1,92 & 1,44 & $<0,001$ & 0,004 & Sim \\
\hline
\end{tabular}

Tabela 4 - Comparação estatística entre os resultados obtidos pelos examinadores pelo Método de Raimondi para a vértebra lombar.

Table 4 - Statistical comparison between the results obtained by the examiners, using the Raimondi method for lumbar vertebrae.

A comparação entre o valor real e conhecido da rotação da vértebra e os valores individuais dos examinadores obtidos pelos métodos de avaliação utilizados no estudo estão ilustrados nas Tabelas 5 e 6. Para o método de Nash \& Moe foi observado concordância dos valores, segundo o coeficiente kappa entre a medida de dois examinadores e os valores reais da rotação da vértebra torácica e lombar. Para o método de Raimondi, utilizando-se o teste "t de Student" e os teste de Wilcoxon foi observado que os valores das medidas dos examinadores divergiram do valor real da rotação da vértebra torácica e lombar.
The comparison among the true and known rotation value of the vertebra and the examiners' individual values obtained with the evaluation methods used in the study are illustrated in Tables 5 and 6 . For the Nash \& Moe method an agreement of the values was observed, according to the coefficient kappa, between the two examiners' measure and the true values of the thoracic and lumbar vertebra rotation. For the Raimondi method, using the "t of Student" test and the Wilcoxon test, it was observed that the values of the examiners' measures diverged from the true value of the thoracic and lumbar vertebra rotations.

\begin{tabular}{|l|c|c|c|c|}
\hline & Coef. Kappa & Desvio padrão & Teste “t” de Student & Nível de Concordância \\
\hline Examinador 1 & 0,41 & 0,17 & $<0,01$ & regular \\
\hline Examinador 2 & 0,04 & 0,14 & $<0,10$ & praticamente inesistente \\
\hline Examinador 3 & 0,04 & 0,14 & $>0,10$ & praticamente inesistente \\
\hline
\end{tabular}

Tabela 5 - Comparação estatística entre os valores das medidas das vértebras torácica e lombar para um mesmo valor conhecido de rotação real pelo método de Nash \& Moe.

Table 5 - Statistical comparison between the measured values of the thoracic and lumbar vertebrae for a same known rotation figure by the Nash \& Moe's method. 


\begin{tabular}{|l|c|c|c|c|c|}
\hline & $\begin{array}{c}\text { Diferença } \\
\text { média }\end{array}$ & $\begin{array}{c}\text { Desvio padrão } \\
\text { da diferença }\end{array}$ & $\begin{array}{c}\text { Nível de } \\
\text { significância (p) }\end{array}$ & Wilcoxon's test & Divergência \\
\hline Examinador 1 & 13,62 & 4,87 & $<0,001$ & 0,001 & Sim \\
\hline Examinador 2 & 13,69 & 5,47 & 0,001 & 0,001 & Sim \\
\hline Examinador 3 & 16,23 & 5,81 & $<0,001$ & 0,001 & Sim \\
\hline
\end{tabular}

Tabela 6 - Comparação estatística entre os valores das medidas das vértebras torácica e lombar para um mesmo valor conhecido de rotação real pelo método de Raimondi.

Table 6 - Statistical comparison between the measured values of the thoracic and lumbar vertebrae for a given known rotation figure by the Raimondi's method.

A correlação entre o valor real e conhecido da rotação da vértebra e a estimada por meio do método de Raimondi está ilustrada na Tabela 7,e por meio do teste do Qui-quadrado para a análise da aderência dos resultados, não tendo sido observada divergência das medidas somente na medida da rotação da vértebra lombar realizada por um dos examinadores.
The correlation among the true and known rotation value for vertebra, and the value estimated with the use of the Raimondi method is illustrated in Table 7, and using the Qui-square test for the analysis of the adherence of the results, with no divergence of the measures observed only in the measure of the lumbar vertebra rotation executed by one of the examiners.

\begin{tabular}{|c|c|c|}
\hline & $\begin{array}{c}\text { Nível de } \\
\text { significância (p) }\end{array}$ & Divergência \\
\hline $\begin{array}{c}\text { Rotação real X Examinador } 1 \\
\text { Vértebra torácica }\end{array}$ & $<0,001$ & $\begin{array}{c}\text { Divergência significativa } \\
\text { gerada em função da } \\
\text { diferênça dos valores até } 20^{\circ}\end{array}$ \\
\hline $\begin{array}{c}\text { Rotação real X Examinador } 1 \\
\text { Vértebra lombar }\end{array}$ & 0,19 & Não significativa \\
\hline $\begin{array}{c}\text { Rotação real X Examinador } 2 \\
\text { Vértebra torácica }\end{array}$ & $<0,001$ & $\begin{array}{c}\text { Divergência significativa } \\
\text { gerada em função da } \\
\text { diferênça dos valores até } 20^{\circ}\end{array}$ \\
\hline $\begin{array}{c}\text { Rotação real X Examinador } 2 \\
\text { Vértebra lombar }\end{array}$ & 0,22 & Não significativa \\
\hline $\begin{array}{c}\text { Rotação real X Examinador } 3 \\
\text { Vértebra torácica }\end{array}$ & $<0,001$ & $\begin{array}{c}\text { Divergência significativa } \\
\text { gerada em função da } \\
\text { diferênça dos valores até } 20 \text { 。 }\end{array}$ \\
\hline $\begin{array}{c}\text { Rotação real X Examinador } 3 \\
\text { Vértebra lombar }\end{array}$ & 0,02 & Significativa \\
\hline
\end{tabular}

Tabela 7 - Correlação estatística entre a rotação real e a rotação estimada pelo método de Raimondi.

Table 7 - Statistical correlation between an actual vertebral rotation and the estimated rotation according to the Raimondi's method.

\section{DISCUSSÃO}

A rotação vertebral para o lado da convexidade da curva escoliótica é uma das características radiográficas da escoliose, e a sua magnitude tem sido correlacionada com o prognóstico, alterações cosméticas e tratamento dos pacientes. O método para a mensuração da rotação vertebral deve ser de baixo custo, preciso e reprodutível ${ }^{(1,5,7,13)}$.

Nesse estudo observamos diferença estatisticamente significativa entre os valores mensurados por diferentes examinadores ao analisar uma mesma radiografia pelo mesmo método. Para o método de Nash e Moe ${ }^{(6)}$ as maiores diferenças ocorreram na análise das radiografias da vértebra torácica, comparada com a mensuração da vértebra lombar. No entanto, foi observada uma boa concordância entre os examinadores. Para o método de Raimondi i(13) houve boa concordância entre os examinadores na mensuração da vértebra torácica, e muita divergência dos resultados da mensuração da vértebra lombar, evidenciando baixa reprodutibilidade do método na vértebra estudada.

\section{DISCUSSION}

The vertebral rotation to the side of the convexity of the scoliotic curve is one of the radiography characteristics of scoliosis, and its magnitude has been correlated with the prognostic, cosmetic alterations and the patients' treatment. The method for the mensuration of the vertebral rotation should have low costs, be precise and reproducible $e^{(1,5,7,13)}$

In that study we observed a statistically significant difference among the values measured by the different examiners when analyzing a same $x$-ray by the same method. For the Nash \& Moe method ${ }^{(6)}$ the largest differences occurred in the analysis of the $x$-rays of the thoracic vertebra, compared with the mensuration of the lumbar vertebra. However, a good agreement was observed among the examiners. For the Raimondi method ${ }^{(13)}$ there was good agreement among the examiners in the mensuration of the thoracic vertebra, and a lot of divergence in the results of the mensuration of the lumbar vertebra, evidencing a low reproducibility of the method in the studied vertebra. 
A comparação dos resultados obtidos pelos 2 métodos, considerando-se o valor real e conhecido da rotação das vértebras, mostrou que os valores não foram concordantes. No método de Nash e Moe os valores obtidos mostraram uma correlação precária entre as vértebras, e na escala de Raimondi os valores observados na análise dos valores conhecidos da vértebra torácica foram significativamente maiores que os da vértebra lombar. Essas observações indicam que as diferenças anatômicas existentes entre as vértebras torácicas e lombares podem conduzir a falsas interpretações na análise das rotações vertebrais, considerando-se os métodos de mensuração utilizados no estudo.

A comparação do valor conhecido da rotação vertebral e o valor observado por meio da mensuração pelo método de Raimondi, mostrou uma diferença significativa dos valores na medida da vértebra torácica, e na vértebra lombar somente a medida de um examinador obteve resultados muito próximos aos reais. Os resultados indicam que para os graus leves de rotação da vértebra torácica , a mensuração da rotação seria prejudicada pela utilização do método de Raimondi. Não foi possível estabelecer esta comparação para o método de Nash e Moe, pois esse método utiliza uma escala graduada e não numérica. No entanto, valores diferentes de rotação receberam a mesma graduação pelo mesmo examinador utilizando essa escala, ficando evidente a sua imprecisão.

É importante salientar que em nosso estudo foram utilizadas vértebras sem alterações morfológicas, e que nessas condições os resultados obtidos não demonstraram precisão na medida dos métodos utilizados, presumindo-se que na presença das alterações morfológicas das vértebras dos pacientes portadores de escoliose possa ocorrer uma ampliação dessa falta de correlação entre os valores reais da rotação e os valores fornecidos pelas mensurações radiográficas.

\section{CONCLUSÕES}

As diferenças anatômicas entre a vértebra torácica e lombar influenciaram na precisão da medida da rotação vertebral e as medidas da rotação vertebral obtidas por meio dos métodos de Nash \& Moe e Raimondi não apresentam estreita correlação ou reproduzem com os valores reais e conhecidos da rotação da vértebra torácica ou lombar.

\section{REFERÊNCIAS BIBLIOGRÁFICAS}

1. Adams W. Lectures on the pathology and treatment of lateral and other forms of curvature of the spine. Churchill and Sons, London, 1865.

2. Bunnel WP. Vertebral rotation: simple method of measurement on routine radiographs (abstract). Orthop Trans 9: 114, 1985.

3. Drerup B. Principles of managment of vertebral rotation from frontal projections of pedicles. J Biomech 17: 923-935, 1984.

4. Filho TEPB, Lech, O Exame Físico em Ortopedia. São Paulo, Sarvier, 27-28, 2001.

5. Goçen, S Havitçioglu, H. Alici, E A new method to measure rotation from CT scans. Eur Spine J 8: 261-265, 1999.

6. Nash CL, Moe JH A study of vertebral rotation. J Bone Joint Surg (Am) 51: 223-229, 1969

7. Omeroglu H, Ozekin O, Biçimoglu A Mesurement of vertebral rotation in idiopathic scoliosis using the Perdriolle torsionmeter: a clinical study on intraobserver and interobserver error. Eur Spine J 5: $167-$ $171,1996$.
The comparison of the results obtained by the 2 methods, considering the true value and known value of the rotation of the vertebrae, showed that the values were not in agreement. In the Nash \& Moe method the obtained values showed a precarious correlation among the vertebrae, and in the Raimondi scale the values observed in the analysis of the known values of the thoracic vertebra were significantly larger than the ones of the lumbar vertebra. Those observations indicate that the existent anatomical differences among the thoracic and lumbar vertebrae can lead to false interpretations in the analysis of the vertebral rotations, taking into consideration the mensuration methods used in the study.

The comparison of the known value of the vertebral rotation and the value observed through the mensuration by the Raimondi method showed a significant difference of the values in the measure of the thoracic vertebra, and in the lumbar vertebra only the measurement of an examiner obtained results very close to the actual values. The results indicate that for the light degrees of rotation of the thoracic vertebra, the mensuration of the rotation would be jeopardized by the use of the Raimondi method. It was not possible to establish this comparison for the Nash method, because that method uses a graduated and not a numeric scale. However, different rotational values received the same graduation for the same examiner using that scale, making evident its imprecision.

It is important to point out that in our study vertebrae were used without morphologic alterations, and that in those conditions the obtained results didn't demonstrate precision in the measurements obtained with the methods used, and it is presumed that an extension of that correlation lack between the actual rotational values and the values supplied by the radiographic mensuration in the presence of morphologic alterations of the scoliosis patients' vertebrae may occur.

\section{CONCLUSIONS}

The anatomical differences among the thoracic and the lumbar vertebrae influenced in the precision of the measurement of the vertebral rotation and the measures of the vertebral rotation obtained by the Nash \& Moe and Raimondi methods don't present a close correlation nor do they reproduce the actual and known values of the thoracic or lumbar vertebrae rotation.

8. Perdriolle R, Vidal J Thoracic idiopathic scolioses curve evolution and prognosis. Spine 10: 785-791, 1985.

9. Richards, SB Measurement error in assessment of vertebral rotation using the Perdriolle torsion meter. Spine 17: 513-517, 1992.

10. Russel GG, Raso, VJ A comparison of four computerized methods for measuring vertebral rotation. Spine 15: 24-27, 1990.

11. Sevastik B, Xiong B, Sevastik J, Hedlund R, Suliman I Vertebral rotation and pedicle length asymmetry in the normal adult spine. Eur Spine 4: 95-97, 1995.

12. Stokes IAF, Three-dimensional terminology of spinal deformity: a report presented to the scoliosis research society by the scoliosis research society working group on 3-D terminology of spinal deformity. Spine 19: 236-248, 1994.

13. Weiss HR, Mesurement of vertebral rotation. Perdriolle versus Raimondi. Eur Spine J 4: 34-38, 1995. 